\title{
USABILITY AND PATIENT ACCEPTANCE OF PREFILLED OR REUSABLE INSULIN PENS
}

\author{
Tek Kullanımlık veya Yeniden Kullanılabılır İnsülin Kalemlerinin Hasta Açısından Kabulü ve \\ Kullanılabilirliği
}

\author{
Ișılay KALAN SARI ${ }^{1}$ iD, Hüseyin DEMIRC $\dot{I}^{2}$ \\ ${ }^{1}$ University of Health Sciences, Antalya Training and Research Hospital, Department of Endocrinology and Metabolic \\ Disorders, ANTALYA, TÜRKIYE \\ ${ }^{2}$ Medicana International Hospital, Department of Endocrinology and Metabolic Disorders, ANKARA, TÜRKIYE
}

Objective: Adherence to insulin therapy is poor in diabetic patients. Insulin pens with many different features have been developed to increase patient satisfaction and compliance to treatment. In our study, we aimed to investigate the usability and acceptance of prefilled or reusable insulin pens.

Material and Methods: One hundred and twenty-six patients with a mean age of $55.3 \pm 11.1$ years were included. Eighty-nine (71\%) patients were female. Sixty-three patients were in prefilled pen group. A questionnaire was used to assess patients' opinions about their use of insulin pens. Glycemic control parameters, demographic characteristics, treatment protocol and microvascular complications were recorded.

Results: There was no significant difference between the two groups for age $(\mathrm{p}=0.3)$, gender $(\mathrm{p}=0.1)$, educational status $(p=0.6)$, duration of diabetes $(p=0.8)$, duration of insulin therapy $(\mathrm{p}=0.2)$ and mean insulin dose $(\mathrm{p}=0.1)$. Ease of use $(\mathrm{p}=0.8)$, ergonomics $(\mathrm{p}=0.3)$, ease of dose selection $(\mathrm{p}=0.6)$, ease of reading the dose scale $(\mathrm{p}=0.3)$ did not significantly differ when two groups were compared. Only the number of patients who found to change the needle as 'moderately difficult' was significantly higher in the prefilled pen group $(\mathrm{p}=0.04)$.

Conclusion: The applicability of the treatment and patient satisfaction is as important as the treatment given to the patients. However we did not find any important difference between prefilled or reusable pen device in terms of usability and patient satisfaction

Keywords: Diabetes mellitus, insulin, injection, patient satisfaction
Amaç: Diyabet hastalarında insülin tedavisine uyum zayıftır. Hasta memnuniyetini ve tedaviye uyumu artırmak için birçok farklı özelliğe sahip insülin kalemleri geliştirilmiştir. Çalışmamızda, tek kullanımlık veya yeniden kullanılabilir kalem kullanan iki hasta grubunda insülin kalemlerinin kullanılabilirliğini ve hasta memnuniyeti üzerindeki etkisini araştırmayı amaçladık.

Gereç ve Yöntemler: Yaş ortalaması $55.3 \pm 11.1$ y1l olan 126 hasta çalışmaya dahil edildi. Hastaların 89 (\%71)'u kadındı. Tek kullanımlık kalem grubunda 63 hasta vardı. İnsülin kalemleri kullanımıyla ilgili hasta görüşlerini değerlendirmek için bir anket kullanıldı. Glisemik kontrol parametreleri, demografik özellikler, tedavi protokolü ve mikrovasküler komplikasyonlar kaydedildi.

Bulgular: İki grup arasında yaş $(\mathrm{p}=0.3)$, cinsiyet $(\mathrm{p}=0.1)$, eğitim durumu $(\mathrm{p}=0.6)$, diyabet süresi $(\mathrm{p}=0.8)$, insülin tedavisi süresi $(p=0.2)$ ve ortalama insülin dozu $(p=0.1)$ açısından anlamlı fark yoktu. Kullanım kolaylığ ${ }^{\prime}(\mathrm{p}=0.8)$, ergonomi $(\mathrm{p}=0.3)$, doz seçimi kolaylığ $(\mathrm{p}=0.6)$ ve doz skalasını okuma kolaylığı $(\mathrm{p}=0.3)$ açısından 2 grup arasında anlamlı farklılık gözlenmedi. Tek kullanımlık kalem grubunda iğne ucu değiştirmeyi "orta derecede zor" olarak değerlendiren hasta sayısı anlamlı olarak daha fazlayd $1(\mathrm{p}=0.04)$.

Sonuç: Hastalara verilen tedavi kadar tedavinin uygulanabilirliği ve hasta memnuniyeti de önemlidir. Ancak çalışmamızda, kullanılabilirlik ve hasta memnuniyeti açısından tek kullanımlık veya yeniden kullanılabilir kalemler arasında ciddi bir fark bulunmamıştır.

Anahtar Kelimeler: Diabetes mellitus, insülin, enjeksiyon, hasta memnuniyeti 


\section{INTRODUCTION}

Diabetes mellitus (DM) is a significant health problem with increasing frequency $(13.7 \%)$ in our country, as in the whole world (1). Although new treatment options have been developed, glycemic targets have not been achieved in many patients which may be associated with decreased adherence to therapies $(2,3)$. Improvement in metabolic control and decrease in glycated hemoglobin (HbA1c) with improved compliance to treatment has been demonstrated in many clinical trials (4-7). When insulin is used at the appropriate dose and with proper injection techniques, it can reduce $\mathrm{HbA1c}$ to target values (8). However, adherence to insulin therapy is poor (9). The reasons for nonadherence are multifactorial. They include age, duration of disease, side effects such as hypoglycemia, weight gain, injection method, and related factors such as ease of injection, needle phobia, and injection pain, clinical utility, patient's confidence in treatment, and cost $(3,10)$. Particularly in type $1 \mathrm{DM}$ and some type $2 \mathrm{DM}$ patients who require multiple injection therapies, the appropriate injection method is gaining importance in treatment compliance. Patients apply insulin mostly with insulin pens, while some type $1 \mathrm{DM}$ patients use an insulin pump. Today, insulin therapy is done with the reusable (with replaceable cartridge) or prefilled (single cartridge) insulin pens. Patients' satisfaction with the insulin pen is essential as it may affect the compliance to the treatment. Our study aims to analyze the simplicity, and acceptability of these two different insulin pen groups among diabetic patients

\section{MATERIALS AND METHODS}

This is a cross-sectional study. A total of 126 patients with type $2 \mathrm{DM}$ aged 18 and over who were admitted to the Endocrinology Polyclinic of Kırıkkale University Faculty of Medicine Hospital between the dates of September 15, 2013, and March 15, 2014, were included. Sixty-three patients were using reusable insulin pens, and 63 were using prefilled insulin pens regularly for at least one month. Patients were using insulin needle tips of the same brand, size, and thickness. Patients who were under the age of 18 , using insulin pen for less than one month, who could not do self-injection (who received insulin injection by their relatives), who used needle tips of different brands, sizes and thicknesses and whose consents were not obtained were not included in the study. After anamnesis and physical examination, patients' written approvals were received. All individuals were asked for fasting blood glucose (FBG), HbA1c, and other required workups regarding their diseases. Patients were asked the questions stated in the questionnaire form presented in the "Appendix." This questionnaire form was filled by evaluating the patients' anamnesis, physical examination, laboratory results, eye department consultation results, as well as the answers received from the patients. The presence of diabetic neuropathy was determined by the signs and symptoms of peripheral neuropathy. Kidney functions of patients were evaluated by serum creatinine, microalbuminuria, and creatinine clearance measurement. After hematuria and urinary infection were excluded, albumin/creatinine ratio values above 30 $\mathrm{mg} / \mathrm{g}$ in the spot urine that was taken at least two times, were accepted as diabetic nephropathy. An ophthalmologist diagnosed diabetic retinopathy after an ophthalmologic examination. We used the Visual Analogue Scale (VAS) to assess the injection pain (11) (Appendix). This research was approved by Kırıkkale University Clinical Research Ethics Committee (Date: 17.07.2013, issue number: 14/01).

\section{Statistical Analysis}

SPSS 16 (Statistical Package for Social Sciences) program was used in the statistical evaluation of the findings in the study. Results were shown as the mean value \pm standard deviation (mean \pm SD). Descriptive statistics were made for all variables. In the determination of the relations between parameters, Pearson correlation analysis was used for the parametric ones, and Spearman correlation analysis was used for 
the nonparametric ones. The results were evaluated within a $95 \%$ confidence interval, and significance was assessed at the $\mathrm{p}<0.05$ level.

\section{RESULTS}

One hundred and twenty-six type $2 \mathrm{DM}$ patients with a mean age of $55.3 \pm 11.1$ years were included. Eighty-nine of the subjects $(71 \%)$ were female, and 37 (29\%) were male. Sixty-five $(51.6 \%)$ patients were primary school graduates, 25 (19.8\%) were high school graduates, 24 (19\%) were university graduates, and 12 (9.5\%) were illiterate. The mean duration of diabetes was $11.8 \pm 7.3$ years, and the mean duration of insulin use was $4.7 \pm 4.8$ years. The mean insulin dose used by the patients was $39.6 \pm 22.9$ IU. The mean HbA1c value of the subjects was $8.4 \pm 1.7 \%$, and the mean FBG value was $177.7 \pm 72.6$ mg/dl. Forty-two (33.3\%) patients had retinopathy, 24 (19\%) had nephropathy and $36(28.6 \%)$ had neuropathy. The study subjects were divided into two groups. Group 1 (n:63) was defined as prefilled pen group, group 2 (n:63) defined as a reusable pen group. Nineteen
(30.2\%) patients in the prefilled pen group had previously used a reusable pen. Only 4 (6.3\%) patients in the reusable pen group had previously experienced a prefilled pen. When the two groups were compared, age, education, mean duration of diabetes, mean duration of insulin use, mean insulin doses, and microvascular complications rates were similar. $\mathrm{HbA} 1 \mathrm{c}$ and $\mathrm{FBG}$ were significantly lower in group $2(\mathrm{p}<0.05)$ (Table 1$)$. Sixtyeight (54\%) patients were using premixed insulin therapy, 29 (23\%) were using basal insulin therapy, and $29(23 \%)$ were using basal-bolus insulin therapy. There was no difference between the two groups in terms of the premixed insulin use rates $(p=1)$. However, basalbolus insulin therapy use was significantly higher, and the rate of only basal insulin therapy use was significantly lower in group $1(\mathrm{p}<0.05)$. In our study, all patients used the same brand and size of the needle tip (32G-6mm). We observed that $53.2 \%$ of the patients used the needle tip once and disposed of it, as recommended, and the other patients used the same needle tip at least twice.

Table 1: Comparison of demographic characteristics, laboratory findings and microvascular complication rates of Group 1 and Group 2 subjects

\begin{tabular}{lccc}
\hline & $\begin{array}{c}\text { Group 1 } \\
\text { (prefilled pen) }\end{array}$ & $\begin{array}{c}\text { Group 2 } \\
\text { (reusable pen) }\end{array}$ & p \\
\hline Age (year) & $56.2 \pm 10.2$ & $54.4 \pm 11.9$ & 0.3 \\
Gender (male/female) n (\%) & $15 / 48(24 / 76)$ & $22 / 41(35 / 65)$ & 0.1 \\
Duration of diabetes (year) & $11.6 \pm 6.8$ & $11.9 \pm 7.9$ & 0.8 \\
Duration of insulin use (year) & $5.3 \pm 5.4$ & $4.2 \pm 4.0$ & 0.2 \\
Insulin dose (IU) & $42.8 \pm 25.6$ & $36.3 \pm 19.5$ & 0.1 \\
Educational Status n (\%) & & \\
Primary School & $36(57.1)$ & $29(46)$ & 0.6 \\
High School & $12(19)$ & $13(20.6)$ & \\
University & $10(15.9)$ & $14(22.2)$ & $7(11.1)$ \\
Illiterate & $5(7.9)$ & $156.9 \pm 80.4$ & $0.001^{*}$ \\
FBG (mg/d) & $198.5 \pm 80.4$ & $8.1 \pm 1.4$ & $0.01^{*}$ \\
HbA1c (\%) & $8.4 \pm 1.7$ & $19(30.2)$ & 0.4 \\
Retinopathy n(\%) & $23(36.5)$ & $10(15.9)$ & 0.3 \\
Nephropathy n(\%) & $14(22.2)$ & $18(28.6)$ & 1 \\
Neuropathy n(\%) & $18(28.6)$ & & \\
\hline
\end{tabular}

Results are stated as mean \pm standard deviation. Significant differences between the groups at $p<0.05$ were highlighted by the '*' sign. 
According to the insulin pen evaluation questionnaire, the evaluations of the patients about insulin pens in terms of ergonomics, ease of needle tip replacement, dose scale readability, dose selection, and the ease of pen use were compared. No patient found the insulin pen ergonomically 'very bad' in both groups. In total, $14.3 \%$ of the patients found the insulin pen ergonomically 'very good'. There was no statistically significant difference between the evaluations of two groups in terms of ergonomics $(p=0.3) \quad$ (Table 2). When patients were asked to evaluate the insulin pen they used in terms of the ease of needle tip replacement, there were no patients who found it 'very difficult'. In total, $34.9 \%$ of the patients found the needle tip replacement 'very easy'. When the two groups were compared, the number of patients who found 'moderately difficult' was significantly higher in the prefilled pen group $(\mathrm{p}=0.04)$ (Table 3). The readability of numbers on the dose scale was evaluated. Of the patients, $7.1 \%$ found the readability of the dose scale as 'very difficult' and $21.4 \%$ of the patients evaluated as 'very easy'. When the patients using prefilled and reusable pen were compared, there was no statistically significant difference between the two groups $(\mathrm{p}=0.3)$ (Table 4). Ease of dose selection while using the insulin pen was evaluated, and $2.4 \%$ of the patients found the dose selection 'very difficult'. Of the patients, $27 \%$ evaluated the dose selection as 'very easy'. When the two groups were compared, there was no statistically significant difference between the evaluations of both groups $(\mathrm{p}=0.6)$ (Table 5). In our study, the ease of using an insulin pen was questioned, and only one person $(0.8 \%)$ evaluated the pen use as 'very difficult' while $27.8 \%$ of the patients evaluated pen to use as 'very easy'. When the patients using prefilled and reusable pens were compared, there was no statistically significant difference between the two groups $(\mathrm{p}=0.8)$ (Table 6). We also asked the patients using reusable pens to evaluate 'the ease of cartridge replacement'. According to the evaluation, no patient found it 'very difficult' while 7 patients $(11.1 \%)$ evaluated as 'difficult', 32 patients $(50.8 \%)$ evaluated as 'moderate', 22 patients (34.9\%) evaluated as 'easy', and 2 patients $(3.2 \%)$ evaluated as 'very easy'.

Table 2: Evaluation of Group 1 and Group 2 patients on the ergonomics of pen use

\begin{tabular}{|c|c|c|c|c|c|c|c|}
\hline & Very good & Good & Moderate & Bad & Very bad & Total & $\mathbf{p}$ \\
\hline \multirow[t]{2}{*}{ Group $1 \mathrm{n}(\%)$} & $8(12.7)$ & 35 & 16 & 4 & - & 63 & 0.3 \\
\hline & & $(55.6)$ & $(25.4)$ & $(6.3)$ & & $(100)$ & \\
\hline \multirow[t]{2}{*}{ Group $2 \mathrm{n}(\%)$} & $10(15.9)$ & 42 & 8 & 3 & - & 63 & \\
\hline & & $(66.7)$ & (12.7) & $(4.8)$ & & $(100)$ & \\
\hline \multirow[t]{2}{*}{ Total n (\%) } & $18(14.3)$ & 77 & 24 & 7 & - & 126 & \\
\hline & & $(61.1)$ & (19.0) & (5.6) & & $(100)$ & \\
\hline
\end{tabular}

$\mathrm{p} \leq 0.05$ is statistically significant

Table 3: Evaluation of Group 1 and Group 2 patients on the ease of needle tip replacement.

\begin{tabular}{lccccccc}
\hline & Very difficult & Difficult & Moderate & Easy & Very easy & Total & p \\
\hline Group 1 n (\%) & - & $2(3.2)$ & $11(17.5)$ & $32(50.8)$ & $18(28.6)$ & $63(100)$ & 0.04 \\
Group 2 $\mathrm{n}(\%)$ & - & $3(4.8)$ & $2(3.2)$ & $32(50.8)$ & $26(41.3)$ & $63(100)$ & \\
Total n $(\%)$ & & $5(4.0)$ & $13(10.3)$ & $64(50.8)$ & $44(34.9)$ & $126(100)$ & \\
\hline
\end{tabular}

$\mathrm{p} \leq 0.05$ is statistically significant 
Table 4: Evaluation of Group 1 and Group 2 patients on the ease of dose scale readability

\begin{tabular}{lccccccc}
\hline & Very difficult & Difficult & Moderate & Easy & Very easy & Total & p \\
\hline Group 1 n (\%) & $2(3.2)$ & $4(6.3)$ & $12(19)$ & $30(47.6)$ & $15(23.8)$ & $63(100)$ & 0.3 \\
Group 2 n (\%) & $7(11.1)$ & $7(11.1)$ & $10(15.9)$ & $27(42.9)$ & $12(19)$ & $63(100)$ & \\
Total n (\%) & $9(7.1)$ & $11(8.7)$ & $22(17.5)$ & $57(45.2)$ & $27(21.4)$ & $126(100)$ & \\
\hline
\end{tabular}

$\mathrm{p} \leq 0.05$ is statistically significant

Table 5: Evaluation of Group 1 and Group 2 patients on the ease of dose selection regarding the pen use

\begin{tabular}{lccccccc}
\hline & Very difficult & Difficult & Moderate & Easy & Very easy & Total & p \\
\hline Group $1 \mathrm{n}(\%)$ & $2(3.2)$ & $3(4.8)$ & $11(17.5)$ & $2(50.8)$ & $15(23.8)$ & $63(100)$ & 0.6 \\
Group 2 $\mathrm{n}(\%)$ & $1(1.6)$ & $4(6.3)$ & $6(9.5)$ & $33(52.4)$ & $19(30.2)$ & $63(100)$ & \\
Total n (\%) & $3(2.4)$ & $7(5.6)$ & $17(13.5)$ & $65(51.6)$ & $34(27)$ & $126(100)$ & \\
\hline
\end{tabular}

$\mathrm{p} \leq 0.05$ is statistically significant

Table 6: Evaluation of Group 1 and Group 2 patients on the ease of pen use

\begin{tabular}{lccccccc}
\hline & Very difficult & Difficult & Moderate & Easy & Very easy & Total & p \\
\hline Group 1 n (\%) & $1(1.6)$ & $1(1.6)$ & $6(9.5)$ & $37(58.7)$ & $18(28.6)$ & $63(100)$ & 0.8 \\
Group 2 n $(\%)$ & $0(0)$ & $1(1.6)$ & $7(11.1)$ & $38(60.3)$ & $17(27)$ & $63(100)$ \\
Total n $(\%)$ & $1(0.8)$ & $2(1.6)$ & $13(10.3)$ & $75(59.5)$ & $35(27.8)$ & $126(100)$
\end{tabular}

$\mathrm{p} \leq 0.05$ is statistically significant

When the features that the patients wanted in the pens were examined; four of the patients who use prefilled pen stated that they want it to be thinner and smaller, one person said that it should require lower pushing power, two people reported that they want it to be convenient for storing at room temperature for longer, two people stated that they want it to have a larger chamber, six people said that they want it to have more significant numbers, one person noted that an automatic needle sterilization system must be developed without the need for needle tip replacement, one person stated that the pen should be more patterned and colored, one person said that there must be less pain. In the patient group using the reusable pen; one person stated that he/she prefers pen to be thinner and smaller, three people indicated that it should require lower pushing power, seven people said that they want it to have more significant numbers, five people stated that there must be less pain, one person noted the pen to be voiced, one person said that he/she prefers pens to have a number indicator light. 


\section{APPENDIX: \\ STUDY QUESTIONNAIRE FORM}

Name and Surname: Age:

Telephone:

Age:

Gender:

Educational status (illiterate, primary, middle, high school, university):

Duration of diabetes mellitus (year):

Duration of insulin use (year):

The brand of insulin pen used:

How long has the patient been using the recommended insulin pen?

Preprandial blood glucose: HbA1c:

Retinopathy (+/-): nephropathy (+/-): neuropathy (+/-):

\section{If using a reusable pen:}

1. Has the patient ever used a prefilled pen before? How long (year)?

2. If used, what are the advantages and disadvantages of the current pen and it:

3. Ease of cartridge replacement:
a) very difficult
b) difficult
c) moderate
d) easy
e) very easy

4. Ergonomics (grasping the pen, shape, color, stability...):
a) very good b) good c) moderate
d) bad
e) very bad

5. Ease of needle tip replacement:
a) very difficult
b) difficult
c) moderate d) easy
e) very easy

6. How many times does the patient use a needle tip?

7. Used needle tip brand:

8. Pain score: No pain unbearable pain

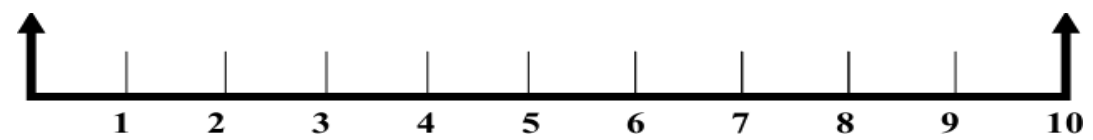

9. Dose scale readability:
a) very difficult
b) difficult
c) moderate
d) easy e) very easy

10. Ease of dose selection (turning the dosimeter, setting odd and even numbers)
a) very difficult
b) difficult c) moderate d) easy
e) very easy

11. Ease of pen use:
a) very difficult
b) difficult
c) moderate
d) easy e) very easy

12. Which insulin is used and the dosage:

13. Features you want:

If using a prefilled pen (FlexPen, KwikPen, Solostar...):

1. Has the patient ever used a reusable pen before? How long (year)?

2. If used, what are the advantages and disadvantages of the current pen and it:

3. Ergonomics (grasping the pen, shape, color, stability...):
a) very good
b) good c) moderate
d) bad
e) very bad

4. Ease of needle tip replacement:
a) very difficult
b) difficult
c) moderate
d) easy e) very easy

5. How many times does the patient use a needle tip?

6. Used needle tip brand:

7. Pain score: No pain unbearable pain

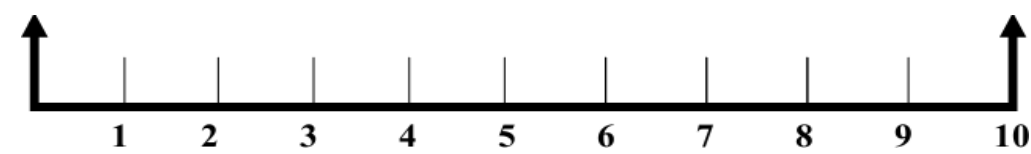

8. Dose scale readability:
a) very difficult $b$ ) difficult
c) moderate
d) easy e) very easy

9. Ease of dose selection (turning the dosimeter, setting odd and even numbers)
a) very difficult
b) difficult
c) moderate d) easy e) very easy

10. Ease of pen use:
a) very difficult b) difficult
c) moderate d) easy
e) very easy

11. Which insulin is used and the dose:

12. Features you want: 


\section{DISCUSSION}

In our study, we examined patients' satisfaction with insulin pens. There was no significant difference between the two groups in terms of ease of pen use, ergonomics, dose scale readability, and ease of dose selection. Only the number of patients who evaluated the needle tip replacement as 'very easy' was higher in the reusable pen group (not statistically significant). In comparison, the number of patients who evaluated as 'moderately difficult' was significantly higher in the prefilled pen group. In literature, insulin pens were mostly compared with syringe and vial in terms of patient satisfaction. In most of these studies, compliance with insulin therapy is higher with insulin pens, and insulin pens contribute to the achievement of glycemic targets (12). Asche et al., examined 39 research results comparing the syringe and insulin pen and observed that treatment compliance increased with insulin pens. Besides, hypoglycemia and rates of hospitalization due to hypoglycemia decreased (13). One study on the elderly diabetic patients reported that patients prefer insulin pens to syringe because of the ease of dose selection, ease of use, and less pain (14). Another study indicated that $74 \%$ of the patients prefer insulin pens in terms of dose scale readability, ease of use, and comfort of use (15). In their study, which they conducted on 1156 patients with type 2 diabetes, Lee et al., showed that treatment compliance increased significantly from $62 \%$ to $69 \%$ when switched from the syringe to pen (16).

Today, to ease the insulin injection and improve treatment compliance, insulin pens with various features and brands have been developed among reusable and prefilled pens. There are many comparative studies among insulin pens in the literature. Still, the majority of these studies are the ones comparing the prefilled pens with each other, and fewer studies are comparing reusable pens with each other. Limitation of movement in the hand joints, defined as the 'cheiroarthropathy', is quite frequent among diabetic patients, especially elderly patients, and causes difficulty in holding and proper injection of insulin $(17,18)$. As a result of diabetic retinopathy, vision problems are common in diabetic patients (19). In these patients, dose adjustment and injection may be guided by the sound produced when adjusting the dose (20). Patients with type $1 \mathrm{DM}$ and some patients with type $2 \mathrm{DM}$ administer basal-bolus insulin therapy. Some patients may confuse these two separate insulin formulations. Patients with type 2 DM are predominantly obese, have insulin resistance, and need higher insulin doses. In studies, the effects of pens on patient preferences and treatment compliance in terms of color, and dose chamber width difference, injection effort difference, audible click sound, ease of grip and ergonomic differences were emphasized. In their studies consisting of 510 patients, Haak et al., have shown that there are differences among the prefilled pens in terms of patient preference and Solostar, in terms of ease of use, is preferred over the FlexPen (21). Ignaut et al., have shown in their studies that KwikPen, in terms of ease of use, ease of pen grip and ease of injection button use, is more preferred over the FlexPen (22). In the study of Klausmann et al. with reusable pens, patients were asked to evaluate Novopen and Humapen in terms of griping, design, dose safety, and preference, and it was observed that Novopen was preferred more by $81 \%$ of the patients (23).

In literature studies, differences between prefilled pen and reusable pen preferences and patient satisfaction have not been clearly defined yet. Some of the reusable pens have a semi-unit dose and memory option. At the same time, there are various features like different color options, higher dose options, distinct audible click sound, and low injection effort among the prefilled pens. The preference of the patient, availability of the pen, the insulin formulation 
in content, price, and the choice of the clinician determine the type of pen used. While in countries such as France, Italy, Spain, Switzerland, Japan, and Turkey, prefilled pens are mostly used; in countries such as Brazil, Canada, Germany, and India, reusable pens are used more. In Australia and the United Kingdom, both pen groups are used approximately equally. The reason for the geographical differences in the use of these pens has not been investigated yet (24). In very few studies comparing prefilled and reusable pens, the preferences of the patients and the ease of use were evaluated, and it was concluded that prefilled pens are more preferred and easier to use. In a study conducted by Asakura et al., prefilled pens FlexPen and OptiClick were compared, and it was observed that the mean injection time was significantly shorter with FlexPen. The patients found the FlexPen easier to use, faster to learn, and more reliable in terms of correct dose application (25). In the study conducted by Reimer et al., FlexPen and Humapen were compared. In this study, it was concluded that patients found both pens similarly reliable, but found FlexPen easier in terms of use, learning and carrying, and the injection time in these pens is shorter (26). The researchers stated that these results are not surprising that cartridge replacement can be complicated if patients are not trained well. Again, anecdotal reports show that patients prefer prefilled pens more because they are thinner, lighter, easier to use, and do not require cartridge replacement (27). However, the half-dose feature and memory function of cartridge-replaceable pens can become important in children and those with insulin sensitivity. The study conducted by Hänel et al., showed that Humapen Luxura pen was more stable when compared with Solostar in terms of dose accuracy (28). In their study in which the pen preferences of patients were examined, Yakushiji et al., reported that patients prefer prefilled pens when they inject themselves and prefer cartridge- replaceable pens when they inject them into another person probably because they are larger (29).

In our study, we did not find significant differences between the two pen groups in terms of ease of use, dose selection, dose scale readability, and ergonomics. The ease of cartridge replacement was also examined in the reusable pen group, and no patients found this 'very difficult'. It was seen that patients did not have any difficulty when replacing the cartridge.

\section{Limitations}

As all the patients could not experience both pen groups and there were pens with different properties in the prefilled and reusable pen groups, a full comparison could not be done. Also, it may be necessary to compare other different characteristics of the pens, such as injection effort, dose accuracy, ease of learning, and audible click sound for an adequate evaluation between the two groups of pens. In conclusion, the applicability of the treatment and patient satisfaction is as important as the treatment given to the patients. However, we did not find any differences between prefilled or reusable pen device in terms of patient satisfaction. Therefore, any type of insulin pen that contains the preferred insulin can be prescribed by clinicians. In order to compare these two groups of pens, further studies are needed that involve more patients, allow patients to experience both groups of pens, and enable patients to evaluate all pen options. In addition to this, further studies are necessary to determine the effect of these two pen groups on patient satisfaction, compliance to treatment, and concerning this on glycemic control.

\section{Conflict of Interest: None}

Support and Acknowledgment: None

Researchers' Contribution Rate Statement: IKS and HD contributed to the main idea and design of the study and prepared the article, IKS and HD collected 
data, IKS took over the writing, IKS and HD contributed to the critical revision of this article. All authors have read the article and confirmed.

Ethics Committe Aproval: Kırıkkale University Clinical Research Ethics Committee; date: 17.07.2013, issue number: 14/01.

\section{REFERENCES}

1. Satman I, Omer B, Tutuncu Y, Kalaca S, Gedik S, Dinccag $\mathrm{N}$ et al. TURDEP-II Study Group. Twelve- year trends in the prevalence and risk factors of diabetes and prediabetes in Turkish adults. Eur J Epidemiol. 2013;28(2):169-80.

2. Hoerger TJ, Segel JE, Gregg EW, Saaddine JB. Is glycemic control improving in U.S. adults? Diabetes Care. 2008;31(1):81-6.

3. García-Pérez LE, Alvarez M, Dilla T, Gil-Guillén V, Orozco-Beltrán D. Adherence to therapies in patients with type 2 diabetes. Diabetes Therapy. 2013;4(2):175-94.

4. Al-Qazaz HKh, Sulaiman SA, Hassali MA, Shafie AA, Sundram S, Al-Nuri R et al. Diabetes knowledge, medication adherence, and glycemic control among patients with type 2 diabetes. Int $\mathbf{J}$ Clin Pharm. 2011;33(6):1028-35.

5. Rhee MK, Slocum W, Ziemer DC, Culler SD, Cook CB, El-Kebbi IM et al. Patient adherence improves glycemic control. Diabetes Educator. 2005;31(2):240-50.

6. Schectman JM, Nadkarni MM, Voss JD. The association between diabetes metabolic control and drug adherence in an indigent population. Diabetes Care. 2002;25(6):1015-21.

7. Kravitz RL, Hays RD, Sherbourne CD, DiMatteo MR, Rogers WH, Ordway L et al. Recall of recommendations and adherence to advice among patients with chronic medical conditions. Arch Intern Med. 1993;153(16):1869-78.
8. Rodbard HW, Jellinger PS, Davidson JA, Einhorn D, Garber AJ, Grunberger G et al. Statement by an American Association of Clinical Endocrinologists/American College of Endocrinology consensus panel on type 2 diabetes mellitus: an algorithm for glycemic control. Endocrine Practice. 2009;15(6):540-59.

9. Bonafede MM, Kalsekar A, Pawaskar M, Ruiz KM, Torres AM, Kelly KR et al. Insulin use and persistence in patients with type 2 diabetes adding mealtime insulin to a basal regimen: a retrospective database analysis. BMC Endocrine Disorders. 2011;11(1):1-9.

10. Stewart KM, Wilson MF, Rider JM. Insulin delivery devices. J Pharm Pract. 2004;17(1):20-8.

11. Wewers ME, Lowe NK. A critical review of visual analog scales in the measurement of clinical phenomena. Res Nurs Health. 1990;13(4):227-36.

12. Marcus A. Diabetes care: Insulin delivery in a changing world. Medscape J Med. 2008;10(5):120.

13. Asche CV, Shane-McWhorter L, Raparla S. Health economics and compliance of vials/syringes versus pen devices: a review of the evidence. Diabetes Technol Ther. 2010;12(1):101-8.

14. Coscelli C, Lostiab S, Lunettac M, Nosarid I, Coronele GA. Safety, efficacy, acceptability of a pre-filled insulin pen in diabetic patients over 60 years old. Diabetes Res Clin Pract. 1995;28(3):173-7.

15. Korytkowski M, Bell D, Jacobsen C, Suwannasari R. A multicenter, randomized, open- label, comparative, two-period crossover trial of preference, efficacy and safety profiles of a prefilled, disposable pen and conventional $\mathrm{vial} /$ syringe for insulin injection in patients with type 1 or 2 diabetes mellitus. Clin Ther. 2003;25(11): 2836-48. 
16. Lee WC, Balu S, Cobden D, Joshi AV, Pashos CL. Medication adherence and the associated health-economic impact among patients with type 2 diabetes mellitus converting to insulin pen therapy: an analysis of third-party managed care claims data. Clin Ther. 2006;28(10):1712-25.

17. Aljahlan M, Lee KC, Toth E. Limited joint mobility in diabetes: Diabetic cheiroarthropathy may be a clue to more serious complications. Postgraduate Medicine. 1999;105(2):99-106.

18. Casanova JE, Casanova JS, Young MJ. Hand function in patients with diabetes mellitus. South Med J. 1991;84(9):1111-3.

19. Aylward GW. Progressive changes in diabetics and their management. Eye. 2005;19(10):1115-8.

20. Asakura T, Seino H. Assessment of dose selection attributes with audible notification in insulin pen devices. Diabetes Technol Ther. 2005;7(4):620-6.

21. Haak T, Edelman S, Walter C, Lecointre B, Spollett G. Comparison of usability and patient preference for the new disposable insulin device Solostar versus FlexPen, lilly disposable pen, and a prototype pen: an open-label study. Clin Ther. 2007;29(4):650-60.

22. Ignaut DA, Schwartz SL, Sarwat S, Murphy HL. Comparative device assessments: Humalog KwikPen compared with vial and syringe and FlexPen. The Diabetes Educator. 2009;35(5):78998.

23. Klausmann G, Hramiak I, Qvist M, Mikkelsen $\mathrm{KH}$, Guo X. Evaluation of preference for a novel durable insulin pen with memory function among patients with diabetes and health care professionals. Patient Prefer Adherence. 2013;7:285-92.

24. Gnanalingham MG, Newland P, Smith CP. Accuracy and reproducibility of low dose insulin administration using pen-injectors and syringes. Arch Disn Child. 1998;79(1):59-62.
25. Asakura T, Jensen KH. Comparison of intuitiveness, ease of use, and preference in two insulin pens. J Diabetes Sci Technol. 2009;3(2):312-9.

26. Reimer T, Hohberg C, Pfützner AH, Jørgensen C, Jensen KH, Pfützner A. Intuitiveness, instruction time, and patient acceptance of a prefilled insulin delivery device and a reusable insulin delivery device in a randomized, open-label, crossover handling study in patients with type 2 diabetes. Clin Ther. 2008;30(12):2252-62.

27. Shaefer CF. The pen is mightier than the sword. Insulin. 2009;4(3):132-5.

28. Hänel H, Weise A, Sun W, Pfützner JW, Thomé N, Pfützner A. Differences in the dose accuracy of insulin pens. J Diabetes Sci Technol. 2008;2(3):478-81.

29. Yakushiji F, Fujita H, Terayama Y, Yasuda M, Nagasawa, Shimojo $M$ et al. The best insulin injection pen device for caregivers: results of injection trials using five insulin injection devices. Diabetes Technol Ther. 2010;12(2):143-8. 